\title{
On Students' De-Motivation, Gender, Major, and Educational Level in Iranian EFL Context
}

\author{
Mohammad Aliakbari ${ }^{1}$ \& Marzieh Hemmatizad ${ }^{2}$ \\ ${ }^{1}$ Department of English, Ilam University, Ilam, Iran \\ ${ }^{2}$ Department of English Language Teaching, Ilam branch, Islamic Azad University, Ilam, Iran \\ Correspondence: Mohammad Aliakbari, Department of English, Ilam University, P. O. Box 516, Ilam 69315, \\ Iran. Tel: 98-0918-341-3283. E-mail: maliakbari@hotmail.com
}

\author{
Received: December 12, 2014 Accepted: January 15, 2015 Online Published: March 25, 2015 \\ doi:10.5539/elt.v8n4p106 URL: http://dx.doi.org/10.5539/elt.v8n4p106
}

\begin{abstract}
The present study investigated de-motivation among Iranian secondary high school and university students with respect to gender, major, and level of education and explored students' experiences in overcoming de-motivation. Data were gathered from 485 participants who comprised 215 male and 270 female. A 35 Likert type item de-motivation questionnaire developed by Sakai and Kikuchi (2009) was administered. Based on factor analysis, five de-motivating factors were identified: Learning Contents and Materials, Teachers' Competence and Teaching Styles, Inadequate School Facilities, Lack of Intrinsic Motivation, and Test Scores. To analyse the collected data Mann-Whitney U and Kruskal-Wallis Test were employed. The results indicated that students' gender and major were influential elements for their motivation, but educational level did not influence students' motivation and also 'Importance of English' was the prominent reason for overcoming de-motivation.
\end{abstract}

Keywords: de-motivation, de-motivational factors, EFL learning, re-motivation

\section{Introduction}

De-motivation is an obstacle in education in which learners do not achieve on their goals. De-motivation is as important as motivation in learning process. Sakai and Kikuchi (2009) stated that "examining the cause of the de-motivation lends support in understanding theories on motivation" (p. 57). De-motivation is viewed as the negative counterpart of motivation. De-motivating factors are elements that lead to diminishing students' motivation to learn English as a foreign language (EFL).Understanding the reasons behind this phenomenon has received due attention by teachers who observe students' de-motivation in the process of learning EFL. Therefore, both teachers and researchers want to know the original sources of students' de-motivation and recently start to investigate in this field. Based on Dörnyei's (2001a) definition, de-motivation can be expressed as "specific external forces that reduce or diminish the motivational basis of behavioural intention or an on-going action" (p. 143).

Learning procedure of a foreign language can be comprised of several factors such as teachers, learners, textbook, content and materials, teaching methods, facilities and so on. Each of them may influence negatively the students' degree of motivation and can have damaging impact on students' outcomes in different stages of learning EFL.

De-motivation is not a permanent phenomenon and de-motivated learners can restore their motivation, this issue of recovering motivation known as re-motivation. According to Ushioda (1998), re-motivation is a process of “getting your motivation online again" (p. 86). Based on Falout's (2012) definition of re-motivation, motivation can be recovered after learners losing it. It can be argued that highly motivated learners are able to recover their motivation well in contrast to low motivated ones after mislaying it.

English as a global language is spoken around the world both as a native and a second or foreign language. It is/has been considered as a vehicle for communication with the international community and it is taught in schools and universities. The problem arises when students become de-motivated to learn English. Perhaps they consider English as a mandatory subject and do not achieve its importance as an instrument for communication. 


\section{Literature Review}

Literature on de-motivation can be categorized into three main subheadings: de-motivation studies in the area of instructional communication, de-motivation studies in language teaching and learning, and studies on Iranian students' EFL learning de-motivation.

\subsection{De-Motivation Studies in the Field of Instructional Communication}

Gorham and Christophel (1992) investigated de-motivational features in college lecture classes among 308 undergraduate college students studying at an American university. Participants listed 2404 motivating/de-motivating factors. From this list, 20 categories were extracted, as follows: Four classes referred to context factors, six categories of motivators indicated structure/format factors, and ten categories were accounted for teacher behaviours. Among the 728 motivating elements, 145 reflected teacher behaviours, 445 concerned context and 138 related to structure/format of the class. Among the 583 de-motivating categories, 198 referred to teacher behaviours, 216 accounted for structure/format and 169 reflected contexts. Thus, researchers concluded that, "motivation is perceived by students as a student-owned state, while lack of motivation is perceived as a teacher-owned problem" (p. 239).

Gorham and Millette (1997) conducted a study in which 224 teachers and students responded to the open -ended question "What do you perceive decreases students' motivation to try to do their best in the class and to achieve your instructional goals"? The findings indicated that three factors were recognized: 1) Context, 2) Structure or format, and 3) Teacher behaviours. Teachers claimed de-motivating factors were related to students. In contrast, students disclosed their de-motivation referred to teachers' characteristics such as presentational way, teaching methods, and incompetence.

Zhang (2007) investigated de-motivating factors among students of four countries such as the U.S., China, German, and Japan. The researcher concluded that the prominent factor was teachers' incompetence and described it as "a cluster of behaviours that reflect teachers' indifference to the students and/or the course" such as "confusing and/or boring lectures, unfair testing, and information overload" (p. 211).

\subsection{De-Motivation Studies in the Language Teaching and Learning}

Oxford (1998) analysed 250 essays of high school and university students. The researcher surveyed students feeling and experiences over a period of time (five years). The analysis of the students' essay revealed four categories of de-motivation: 1) teachers' behaviours in relation to the students, 2) the teachers' attitude towards the course or context and material, 3) style conflicts between teachers and students, and 4) the nature of the classroom activities.

In another investigation, Ushioda (1998) surveyed the 20 university learners' ideas of motivation, their experiences on degrees of motivation during time, and what elements they perceived as de-motivating factors in their L2 learning. The researcher utilized structured interview for collecting data. The findings were the same as conclusions of previous studies. In other words, de-motivational factors were extracted from external factors rather than internal factors. External factors were: specific teaching methods, style, and learning tasks. Thus, Ushioda focused on students' capability to "limit their loss of motivation damage and dissociate the negative affect they are currently experiencing from their own enduring motivation for wanting to learn the language" (p. 121).

Chambers (1999) studied de-motivation in the area of L2 learning and examined de-motivated learners in four schools in Leeds, UK. The researcher administered a questionnaire to 191 students. Seven teachers also completed another questionnaire. Teachers defined de-motivated students in the following ways: 1) lacking of enthusiasm, motivation, and concentration on the learning process, 2) lacking of self-confidence and eagerness in doing home works, 3) distracting other students in class.

Students considered teachers as the main source of de-motivation, unlike teachers who did not perceive themselves as a de-motivating factor. Students also reproached their teachers for: 1) having out of date teaching method, 2) giving insufficient description on lesson, 3) having bad temperate when they do not understand, and 4) not using up-to-date equipment.

Moreover, Williams, Burden, and Lanvers (2002) examined students' motivation in secondary school in learning foreign languages at the south-west of England. They constructed a survey and interviews respectively, to analyse students' answers on 16 constituents connected to motivation. The questionnaire was distributed among 228 students in years 7,8 , and 9 . They found that motivation decreased with age and higher motivation level was observed among females than males. Findings also revealed a higher motivation existed for learning German than French. 
The studies by Chambers and Ushioda focused on de-motivational factors as constituents of motivation while the studies by Dörnyei and Oxford focused especially on de-motivation by itself.

In this line, Bednarova (2011) investigated the negative impact of de-motivational factors on learners' motivation in learning English. The study was unique in discovering the source of de-motivation from learners' perspective by providing their experiences in mislaying initial motivation and the reasons to cope with de-motivation. The qualitative method was employed for gathering data. Based on an/the analysis of 54 learners' essays, the findings revealed that de-motivation was a crucial problem that negatively affected students' motivation and behaviour in learning English as a second language (ESL). The results also indicated that external factors were more de-motivating than internal ones and that 'the teachers' were the prominent element of de-motivation that was perceived by learners.

\subsection{Studies on Iranian Students' EFL Learning De-Motivation}

In line with other countries around the world, Iran as an EFL context is no exception. When English was spread widely as an international language, much attention was paid on learning English in the Iranian context. Meanwhile, the extension of students' de-motivation in EFL learning should not be ignored. Therefore, Iranian researchers recently have embarked on investigating this domain. Although some studies were conducted on de-motivation and de-motivating factors in the classroom and among the students, but it seems that very few studies have been carried out in this area.

Kaivanpanah and Ghasemi (2011) examined the main sources of de-motivation in EFL learning and analysed students' gender and educational level with respect to de-motivating factors. In order to gather data a questionnaire comprising of 32 items was developed and filled by 327 students. Based on factor analysis five categories emerged: 1) Learning contents, materials, and facilities, 2) Attitude towards English speaking community, 3) The teacher, 4) Experience of failure, and 5) Attitude towards second language learning. Two one-way tests of variance were run to analysis students' gender and levels of education in relation to de-motivating factors. The 'learning contents, materials, and facilities' was the major source of de-motivation and female students were more de-motivated than male ones. Findings also indicated that 'Attitude towards English speaking community' was the main source of de-motivation for university students than junior high school and high school students.

Another study was conducted by Alavinia and Sehat (2012) to investigate Iranian students' de-motivating factors. The researchers utilized a questionnaire developed by Sakai and Kikuchi (2009), Warrington (2005), and Muhonen (2004). The second questionnaire was an open-ended question about what elements contribute to students' de-motivation and was filled by teachers. The results demonstrated there is no significant difference among the classes except for the factors related to the teachers' behaviour and personality and also learner's and learner's experience of failure. The findings also indicated that both internal and external factors might de-motivate learners.

Moreover, Molavi and Biria (2013) attempted to investigate the significant difference between the achievement of 50 motivated and de-motivated Iranian seminary students in EFL learning. The three questionnaires and tests were employed for collecting data. At the first, 50 students were selected through the application of Oxford Placement Test (OPT) in order to choose intermediate homogenous students. The next step was the application of Gardner's Attitude/ Motivated Test Battery (AMTB) to select motivated and de-motivated students. In the final step, Interchange Objective Placement Test (IOPT) was conducted on students to check students' English Proficiency. The finding revealed that de-motivation influenced EFL learning certainly and students with high score in AMTB had high score in proficiency test as well.

Along the same line, Hosseini and Jafari (2014) surveyed 604 Iranian secondary school students' de-motivation comprising 318 male and 286 female students. A de-motivation questionnaire and extra question about students' experiences on their motivation to learn English was administered. The findings indicated that based on principal factor analysis, three factors were identified: a) Insufficient school facilities, b) Inappropriate teaching materials and contents, and c) A dearth of intrinsic motivation. The last item was recognized as the main source of de-motivation. The results also illustrated that inappropriate teaching materials and contexts was the major de-motivating factor for more and less motivated learners. The roles of such factors are to be explored in the present study, the explicit explanation of which comes in the following sections.

\section{Statement of the Problem}

In countries where English is taught and learnt as a foreign language, learners confront with some problems due to many different factors such as lack of language learning facilities or equipment, learning conditions, teaching 
method and behaviors. Therefore, over a long period of time learners may become de-motivated because of a series of elements which affect them negatively. Just in the recent years, de-motivation research was regarded as a vital component in EFL learning and teaching. Over the past decades, "motivation" had central role in the process of learning a foreign language and researchers paid more attention on this positive section and neglected the other side known as de-motivation that decreases the eagerness and motivation degree.

Learners in the Iranian context are not exception from the damaging impact of de-motivation on their outcomes in the EFL learning procedures. Students who experience de-motivation form negative attitudes towards learning English. It may be considered as a source of lack of intrinsic motivation. Moreover, students may not match learning contents and materials to their actual application in authentic conditions and they do not have any chance to communicate with native speakers of English. In such situations, de-motivated learners look for the way to pass tests successfully without any effort to achieve the real goal of learning EFL as a vehicle for communication. So, the discovering and removing of de-motivating factors origin may be useful for both teacher and learners and in wide dimension for educational system of Iranian context.

Thus, the present study aimed to probe the issue of de-motivation in the Iranian high schools and universities. The researchers strive to probe the possible difference between students' levels of education, majors, and gender with respect to the role of different de-motivators and to reveal the elements that help students overcome de-motivating factors.

The present study seeks answer to the following questions:

1) Does students' level of de-motivation vary with respect to their gender, level of education, and major?

2) What factors can help students overcome de-motivation?

\section{Methodology}

\subsection{Participants}

Four hundred and eighty five Iranian EFL learners from 9 secondary high schools and 4 universities at Ilam city were selected through the convenience sampling method. Out of 485 participants 215 were male and 270 were female students. Participants who took part in the study consisted of 309 participants (161 male and 148 female) in the secondary high school and 176 participants (54 male and 122 female) in the university. Moreover, a large proportion of participants were students of secondary high school which categorized into Sophomore 137 (28.2\%) and Junior $172(35.5 \%)$ and also university students were at Bachelor degree $176(36.3 \%)$. The major of participants categorized into Experimental Sciences 121 (24.9\%), Mathematics 101 (20.8\%), and Humanities 87 $(17.9 \%)$ in the secondary high school and also Educational field of university students classified into Biology 26 (5.4\%), Chemistry 50 (10.3\%), Law 62 (12.8\%), and Social sciences 38 (7.8\%).

\subsection{Instruments and Materials}

A questionnaire with 35 five point Likert scale questions on de-motivating factors developed by Sakai \& Kikuchi (2009) was employed in the current study. In line with Sakai and Kikuchi (2009) study, the questionnaire was designed to measure five de-motivating factors: 1) Learning Contents and Materials, 2) Teachers' Competence and Teaching Styles, 3) Inadequate School Facilities, 4) Lack of Intrinsic Motivation), and 5) Test Scores. The participants were asked to choose one of the five options: a) Not true; b) Mostly not true; c) Not either true or untrue; d) To some extent true; and e) True.

Another question was used to obtain students' opinion about factors that help them cope with de-motivating factors. This open-ended questionnaire was adapted from the research previously conducted on de-motivation (Bednarova, 2011). It was used to examine whether or not students were able to overcome de-motivation, and their experiences in coping with de-motivation (How have you managed to retrieve your interest in learning English?)

Sakai and Kikuchi (2009) determined the internal-consistency reliability of the survey by using Cronbach's Alpha. The result indicated that the five factors extracted from de-motivation questionnaire have above average reliability ranging from .73-.83. In the current study, the reliability of five factors was computed using Cronbach's Alpha. The result demonstrated that reliability Coefficients was .89. Concerning the validity of the instrument, Iranian university professors confirmed its appropriateness for Iranian context as well.

\subsection{Data Collection Procedure}

After obtaining the consent of Education office of Ilam city and Ilam University, Payam-e-nour University, and Institute of Applied Science Technology of Ilam the present study set out. In the second two weeks of April 2014, the Persian translation version of the de-motivation questionnaire was administered to secondary high school and 
university students. To ease the process of responding and removing problems in relation to the contents of questionnaire, participants were recommended to ask any question in this respect.

\subsection{Data Analysis Procedure}

In the current study quantitative and qualitative methods were employed for collecting data. For quantitative analysis, descriptive statistics, frequencies, means, and standard deviation were computed for students' answers to the 35 items of de-motivation factors. Moreover, inferential statistics of non-parametric Mann-Whitney U and Kruskal Wallis Tests were utilized to analyse extracted data for responding the main research question.

In qualitative analysis, students' answers to the open-ended question were analysed (How have you managed to retrieve your interest in learning English?). Initially, secondary high school and university students' answers were translated and coded which deal with reasons helped them cope with de-motivation. So, the categorization and sub categorization were employed after reading students' opinions in their writings. Then, frequency, percentage, and order were run for each category.

\section{Results}

\subsection{Normality Distribution Test of Data}

To investigate the normality distribution of variables the Kolmogorov-Smirnov Test was utilized. Mean, standard deviation, and significance level for each item of questionnaire were computed. Findings indicated that the obtained significance level is lower than $\mathrm{p}<0.05$ and distribution of variables are not normal. Therefore, none of the factors follow the normality distribution and to investigate the research question, non-parametric test of Mann-Whitney U and Kruskal-Wallis Test were applied.

\subsection{Inferential Statistics}

According to the results of Kolmogorov-Smirnov Test, to investigate the first research question of the study non-parametric test of Mann-Whitney $U$ and Kruskal-Wallis Test were run. To analyse the main research question (Does students' level of de-motivation vary with respect to gender, level of education, and major?), the researchers subdivided it into three sections which are discussed in the following parts:

\subsubsection{De-Motivating Factors and Students' Gender}

To analyse whether de-motivating factors differ between male and female students in the secondary high school and university, Mann Whitney U Test was run. According to Table 1, the obtained significance level of all factors except for Teachers' Competence and Teaching Styles is lower than $p<0.05$, indicating that there is a statistically significant difference between male and female students in secondary high school with regard to the factors of Learning Contents and Materials, Inadequate School Facilities, Test Scores, Lack of Intrinsic Motivation. No significant differences were found between two groups in terms of Teachers' Competence and Teaching Styles.

Table 1. Mann-Whitney U Test results for gender for secondary high school students

\begin{tabular}{|c|c|c|c|c|c|c|c|}
\hline De-motivating Factors & Gender & $\mathrm{N}$ & Mean rank & Sum of Rank & Mann-Whitney U & $\mathrm{Z}$ & Sig \\
\hline \multirow{3}{*}{$\begin{array}{l}\text { Learning Contents and } \\
\text { Materials }\end{array}$} & Male & 161 & 134.67 & 21682.50 & & & \\
\hline & Female & 148 & 177.11 & 26212.50 & 8641.50 & -4.174 & 0.000 \\
\hline & Total & 309 & & & & & \\
\hline \multirow{3}{*}{$\begin{array}{l}\text { Teachers' Competence } \\
\text { and Teaching Styles }\end{array}$} & Male & 161 & 145.58 & 23438 & & & \\
\hline & Female & 148 & 165.25 & 24457 & 10397 & -1.936 & 0.053 \\
\hline & Total & 309 & & & & & \\
\hline \multirow{3}{*}{$\begin{array}{l}\text { Inadequate } \\
\text { Facilities }\end{array}$} & Male & 161 & 130.80 & 21058.50 & & & \\
\hline & Female & 148 & 181.33 & 26836.50 & 8017.50 & -4.980 & 0.000 \\
\hline & Total & 309 & & & & & \\
\hline \multirow[t]{3}{*}{ Test Scores } & Male & 161 & 135.46 & 21808.50 & & & \\
\hline & Female & 148 & 176.26 & 26086.50 & 8767.50 & -4.017 & 0.000 \\
\hline & Total & 309 & & & & & \\
\hline \multirow{3}{*}{$\begin{array}{l}\text { Lack of } \\
\text { Motivation }\end{array}$} & Male & 161 & 136.02 & 21899 & & & \\
\hline & Female & 148 & 175.65 & 25996 & 8858 & -3.908 & 0.000 \\
\hline & Total & 309 & & & & & \\
\hline
\end{tabular}


As can be observed in Table 2, the significance level of all factors except for the factor of Teachers' Competence and Teaching Styles is higher than $p<0.05$, so there is no significant difference between male and female students of university with respect to de-motivating factors except for the factor of Teachers' Competence and Teaching Styles.

Table 2. Mann-Whitney U Test results for gender for university students

\begin{tabular}{|c|c|c|c|c|c|c|c|}
\hline De-motivating Factors & Gender & $\mathrm{N}$ & Mean rank & Sum of rank & Mann-Whitney U & $\mathrm{Z}$ & Sig \\
\hline \multirow{3}{*}{$\begin{array}{l}\text { Learning Contents and } \\
\text { Materials }\end{array}$} & Male & 54 & 97.50 & 5265 & & & \\
\hline & Female & 122 & 84.52 & 10311 & 2808 & -1.561 & 0.119 \\
\hline & Total & 176 & & & & & \\
\hline \multirow{3}{*}{$\begin{array}{l}\text { Teachers' Competence } \\
\text { and Teaching Styles }\end{array}$} & Male & 54 & 102.90 & 5556.50 & & & \\
\hline & Female & 122 & 82.13 & 10019.50 & 2516.50 & -2.499 & 0.012 \\
\hline & Total & 176 & & & & & \\
\hline \multirow{3}{*}{$\begin{array}{l}\text { Inadequate University } \\
\text { Facilities }\end{array}$} & Male & 54 & 93.25 & 5035.50 & & & \\
\hline & Female & 122 & 86.40 & 10540.50 & 3037.50 & -0.827 & 0.408 \\
\hline & Total & 176 & & & & & \\
\hline \multirow[t]{3}{*}{ Test Scores } & Male & 54 & 92.56 & 4998 & & & \\
\hline & Female & 122 & 86.70 & 10578 & 3075 & -0.704 & 0.481 \\
\hline & Total & 176 & & & & & \\
\hline \multirow{3}{*}{$\begin{array}{l}\text { Lack of } \\
\text { Motivation }\end{array}$} & Male & 54 & 91.55 & 4943.50 & & & \\
\hline & Female & 122 & 87.15 & 10632.50 & 3129.50 & -0.529 & 0.597 \\
\hline & Total & 176 & & & & & \\
\hline
\end{tabular}

\subsubsection{De-Motivating Factors and Students' Educational Level}

The second section analysed whether de-motivating factors differ with students' level of education in the secondary high school and university.

Table 3. The results of Kruskal-wallis Test for educational level in both groups

\begin{tabular}{|c|c|c|c|c|c|c|}
\hline De-motivating Factors & Educational level & $\mathrm{N}$ & Mean Rank & Chi-square & Df & Sig \\
\hline \multirow{4}{*}{$\begin{array}{l}\text { Learning Contents and } \\
\text { Materials }\end{array}$} & Junior & 172 & 243.85 & \multirow{4}{*}{0.218} & \multirow{4}{*}{2} & \multirow{4}{*}{0.897} \\
\hline & Sophomore & 137 & 246.63 & & & \\
\hline & Bachelor degree & 176 & 239.34 & & & \\
\hline & Total & 485 & & & & \\
\hline \multirow{4}{*}{$\begin{array}{l}\text { Teachers' Competence } \\
\text { and Teaching Styles }\end{array}$} & Junior & 172 & 244.50 & \multirow{4}{*}{4.336} & \multirow{4}{*}{2} & \multirow{4}{*}{0.114} \\
\hline & Sophomore & 137 & 223.57 & & & \\
\hline & Bachelor degree & 176 & 256.66 & & & \\
\hline & Total & 485 & & & & \\
\hline \multirow{4}{*}{$\begin{array}{l}\text { Inadequate } \\
\text { Facilities }\end{array}$} & Junior & 172 & 246.90 & \multirow{4}{*}{0.654} & \multirow{4}{*}{2} & \multirow{4}{*}{0.721} \\
\hline & Sophomore & 137 & 246.83 & & & \\
\hline & Bachelor degree & 176 & 256.66 & & & \\
\hline & Total & 485 & & & & \\
\hline \multirow[t]{4}{*}{ Test Scores } & Junior & 172 & 234.15 & \multirow{4}{*}{1.995} & \multirow{4}{*}{2} & \multirow{4}{*}{0.369} \\
\hline & Sophomore & 137 & 239.22 & & & \\
\hline & Bachelor degree & 176 & 254.59 & & & \\
\hline & Total & 485 & & & & \\
\hline \multirow{4}{*}{$\begin{array}{l}\text { Lack of } \\
\text { Motivation }\end{array}$} & Junior & 172 & 248.56 & \multirow{4}{*}{1.384} & \multirow{4}{*}{2} & \multirow{4}{*}{0.501} \\
\hline & Sophomore & 137 & 231.16 & & & \\
\hline & Bachelor degree & 176 & 246.79 & & & \\
\hline & Total & 485 & & & & \\
\hline
\end{tabular}


To investigate this section of research question, Kruskal-Wallis Test was utilized. As can be seen in Table 3, the obtained level of significance for all factors is higher than $p<0.05$. So, the findings indicate that there is no significant difference between educational levels of students with respect to de-motivating factors.

\subsubsection{De-Motivating Factors and Students' Major}

The third section of research question examined whether de-motivating factors vary among students of different major in secondary high school and university. To address this section of research question, Kruskal-Wallis Test was employed.

Table 4 demonstrates that obtained level of significance in this analysis for all factors is lower than $\mathrm{p}<0.05$. Therefore, there is a statistically significant difference between secondary high school students' majors with regard to de-motivating factors.

Table 4. The results of Kruskal-Wallis Test for major for the secondary high school students

\begin{tabular}{|c|c|c|c|c|c|c|}
\hline De-motivating factors & Major & $\mathrm{N}$ & Mean rank & Chi-square & Df & Sig \\
\hline \multirow[t]{4}{*}{$\begin{array}{l}\text { Learning Contents and } \\
\text { Materials }\end{array}$} & $\begin{array}{l}\text { Experimental } \\
\text { Sciences }\end{array}$ & 121 & 149.94 & 17.687 & 2 & 0.000 \\
\hline & Humanities & 101 & 183.21 & & & \\
\hline & Mathematics & 87 & 129.29 & & & \\
\hline & Total & 309 & & & & \\
\hline \multirow[t]{4}{*}{$\begin{array}{l}\text { Teachers' Competence } \\
\text { and Teaching Styles }\end{array}$} & $\begin{array}{l}\text { Experimental } \\
\text { Sciences }\end{array}$ & 121 & 151.81 & 12.856 & 2 & 0.002 \\
\hline & Humanities & 101 & 178.50 & & & \\
\hline & Mathematics & 87 & 132.17 & & & \\
\hline & Total & 309 & & & & \\
\hline \multirow[t]{4}{*}{$\begin{array}{l}\text { Inadequate } \\
\text { Facilities }\end{array}$} & $\begin{array}{l}\text { Experimental } \\
\text { Sciences }\end{array}$ & 121 & 166.05 & 6.131 & 2 & 0.047 \\
\hline & Humanities & 101 & 158.47 & & & \\
\hline & Mathematics & 87 & 135.61 & & & \\
\hline & Total & 309 & & & & \\
\hline \multirow[t]{4}{*}{ Test Scores } & $\begin{array}{l}\text { Experimental } \\
\text { Sciences }\end{array}$ & 121 & 134.29 & 28.859 & 2 & 0.000 \\
\hline & Humanities & 101 & 194.04 & & & \\
\hline & Mathematics & 87 & 138.48 & & & \\
\hline & Total & 309 & & & & \\
\hline \multirow[t]{4}{*}{$\begin{array}{l}\text { Lack of } \\
\text { Motivation }\end{array}$} & $\begin{array}{l}\text { Experimental } \\
\text { Sciences }\end{array}$ & 121 & 136.49 & 27.295 & 2 & 0.000 \\
\hline & Humanities & 101 & 192.99 & & & \\
\hline & Mathematics & 87 & 136.65 & & & \\
\hline & Total & 309 & & & & \\
\hline
\end{tabular}

As Table 5 reveals, the obtained significance level for the two factors Teachers' Competence and Teaching Styles and Inadequate University Facilities is higher than $p<0.05$. So, there is no significant difference between students at different majors with respect to the two stated factors, but there is a statistically significant difference between university students' majors in terms of Learning Contents and Materials, Test Scores, and Lack of Intrinsic Motivation factors. 
Table 5. The results of Kruskal-Wallis Test for educational field for university students

\begin{tabular}{|c|c|c|c|c|c|c|}
\hline De-motivating Factors & Educational field & $\mathrm{N}$ & Mean rank & Chi-square & Df & Sig \\
\hline \multirow{5}{*}{$\begin{array}{l}\text { Learning Contents and } \\
\text { Materials }\end{array}$} & Biology & 26 & 78.23 & & & \\
\hline & Chemistry & 50 & 87.73 & & & \\
\hline & Law & 62 & 109.67 & 17.748 & 3 & 0.000 \\
\hline & Social Sciences & 38 & 69.89 & & & \\
\hline & Total & 176 & & & & \\
\hline \multirow{5}{*}{$\begin{array}{l}\text { Teachers' Competence } \\
\text { and Teaching Styles }\end{array}$} & Biology & 26 & 88.13 & & & \\
\hline & Chemistry & 50 & 84.59 & & & \\
\hline & Law & 62 & 91.83 & 0.563 & 3 & 0.905 \\
\hline & Social Sciences & 38 & 88.46 & & & \\
\hline & Total & 176 & & & & \\
\hline \multirow{5}{*}{$\begin{array}{l}\text { Inadequate } \\
\text { Facilities }\end{array}$} & Biology & 26 & 64.63 & & & \\
\hline & Chemistry & 50 & 87.98 & & & \\
\hline & Law & 62 & 95.89 & 7.456 & 3 & 0.059 \\
\hline & Social Sciences & 38 & 93.46 & & & \\
\hline & Total & 176 & & & & \\
\hline \multirow[t]{5}{*}{ Test Scores } & Biology & 26 & 96.27 & & & \\
\hline & Chemistry & 50 & 66.87 & & & \\
\hline & Law & 62 & 101.86 & 13.975 & 3 & 0.003 \\
\hline & Social Sciences & 38 & 89.84 & & & \\
\hline & Total & 176 & & & & \\
\hline \multirow{5}{*}{$\begin{array}{l}\text { Lack of } \\
\text { Motivation }\end{array}$} & Biology & 26 & 81.92 & & & \\
\hline & Chemistry & 50 & 63.02 & & & \\
\hline & Law & 62 & 104.01 & 21.156 & 3 & 0.000 \\
\hline & Social Sciences & 38 & 101.22 & & & \\
\hline & Total & 176 & & & & \\
\hline
\end{tabular}

The second research question of the study was: "What factors can help students overcome de-motivation?" To understand how students had managed to defeat de-motivation, the answers to this question was analysed. Out of 485 participants 216 answered the open question. Then, translation and coding were done for the students' essay and qualitative analysis began by recording factors that emerged from data. The frequency, per cent, and order of factors with subcategories that helped students for overcoming de-motivation in English class are provided in Table 6 .

Based on Table 6, eight factors that significantly contributed to students' overcoming de-motivation were respectively: 1) Importance of English (Percent=\%29.4, Frequency=63) included four subcategories of Realizing the importance of English in Konkur, Realizing the importance of English in society, Realizing the importance of English in university, and Realizing the importance of English, 2) Personal Reasons (Percent $=\% 17.2$, Frequency $=38$ ) consisted three subcategories of Being able to communicate with other people in the broad, Not feeling inferior in front of expert friend, and Being able to translate English songs into Persian, 3) English as lingua franca (Percent $=\% 16$, Frequency $=34$ ) entailed one subcategory of Recognizing English as an international language, 4) Attitudes towards English (Percent $=\% 9.7$, Frequency=21) comprised one subcategory of Finding English itself as an interesting language, 5)Teaching methods (Percent $=\% 8.3$, Frequency $=18$ ) contained one subcategory of Finding teaching methods better and more effective, 6) Self-improvement (Percent $=\% 7.8$, Frequency=17) included one subcategory of Practicing English at home, 7) Learning conditions (Percent $=\% 7$, Frequency=15) involved one subcategory of Accessing of learning English institute, and 8) External encouragement (Percent $=\% 4.6$, Frequency $=10$ ) also comprised one subcategory of Supporting and encouraging of parents. 
Table 6. Reasons for overcoming de-motivation in secondary high school and university

\begin{tabular}{lll}
\hline Factors & Frequency & Percent \\
\hline 1. Importance of English & $\mathbf{6 3}$ & 29.4 \\
- Realizing the importance of English in Konkur & 19 & \\
- Realizing the importance of English in society & 19 & \\
- Realizing the importance of English in university & 14 & \\
- Realizing the importance of English & 11 & 17.2 \\
2. Personal reason & $\mathbf{3 8}$ & \\
- Being able to communicate with other people in the broad & 21 & \\
- Not feeling inferior in front of expert friend & 12 & 16 \\
- Being able to translate English songs into Persian & 5 & \\
3. English as lingua franca & $\mathbf{3 4}$ & 9.7 \\
- Recognizing English as an international language & 34 & 8 \\
4. Attitudes towards English & $\mathbf{2 1}$ & \\
- Finding English itself as an interesting language & 21 & 7.8 \\
5. Teaching methods & $\mathbf{1 8}$ & \\
- Finding teaching methods better and more effective & 18 & 7 \\
6. Self-improvement & $\mathbf{1 7}$ & \\
- Practicing English at home & 17 & 4.6 \\
7. Learning condition & $\mathbf{1 5}$ & \\
- Accessing of learning English institute & 15 & $\mathbf{1 0}$ \\
8. External encouragement & 10 & \\
-Supporting and encouraging of parents &
\end{tabular}

\section{Discussion and Conclusion}

The current study intended to investigate students' de-motivating factors in EFL learning in the Iranian context in relation to gender, level of education, and major and also to identify the factors that assist students overcome de-motivating factors. In line with Sakai and Kikuchi's (2009) study, the result of principal component analysis with Oblimin rotation indicated that de-motivating questionnaire consisted of five factors: Learning Contents and Materials, Teachers' Competence and Teaching Styles, Inadequate School Facilities, Lack of Intrinsic Motivation, and Test Scores.

While previous studies ignored the role of the gender, the present study examined the differences between male and female students with respect to de-motivating factors. The results revealed that in the secondary high school based on mean rank, female students were more de-motivated than male students in relation to four de-motivational factors 'Inadequate School and University Facilities', 'Test Scores', Lack of Intrinsic Motivation', and Learning Contents and Material. In the university group in line with Muhonen's (2004) findings, in the current study male students were more de-motivated than female students with respect to the 'Teachers' Competence and Teaching Styles' factor. Moreover, no significant differences were found between the two groups in terms of 'Inadequate School and University Facilities', 'Test Scores', Lack of Intrinsic Motivation', and Learning Contents and Material.

The examination of de-motives in relation to students' level of education demonstrated that significant differences were not found between students' level of education and de-motivating factors in both university and secondary high school and it implied that students' educational level do not seem to be an influential element on their motivation.

The analysis of de-motives in relation to students' major in the secondary high school revealed that 'Test Scores', 'Lack of Intrinsic Motivation', 'Teachers' competence and Teaching styles', and 'Learning Contents and Materials' factors were respectively more de-motivating for Humanities students than Mathematics and Experimental Sciences students. In fact Humanities students' considered these factors more de-motivating in learning English. Perhaps they had more negative attitudes towards foreign language learning. In addition, 'Inadequate school Facilities' was more de-motivating for Experimental Sciences students than Mathematics and Humanities students.

Moreover, the analysis of de-motivating factors with respect to students' major in university demonstrated 
learners' major are supposed to be an influential element on their motivation in terms of 'Test Scores', 'Lack of Intrinsic Motivation', and Learning Contents and Materials'. According to the mean rank these factors were more de-motivating for Law students than Biology, Chemistry, and Social Science students.

According to the students' answers in the Result section, learners identified English as a global language and realized its importance in Konkur, society, and university. Therefore, they stated, 'Importance of English' is the most prominent factor for overcoming de-motivation. Learners explained they are interested in learning English due to some reasons such as personal reasons (being able to communicate with other people in the broad, not feeling inferior in front of expert friend, and being able to translate English songs into Persian), English as lingua franca, and positive attitudes towards English and teaching methods. It can be argued these factors help students to overcome de-motivation or re-motivate their motivation to learn English as a foreign language.

This study focused on students' de-motivational factors with respect to gender, level of education, and major in secondary high school and university, it can be extended to the language institute and the first grade of high school and also can be extended to reveal teachers' de-motivational factors. The current study utilized survey method in its design. Therefore, it is better to accomplish a case study method due to de-motivational factors change during time which can only be investigated by a longitudinal method as Ushioda (2001) claimed de-motivation varies over a period of time according to the predominant conditions.

\section{References}

Alavinia, P., \& Sehat, R. (2012). A probe in to the main de-motivating factors among Iranian EFL learners. Published by Canadian Center of Science and Education, 15(6), 9-35. http://dx.doi.org/10.5539/elt.v5n6p9

Bednarova, N. (2011). De-motivating influences for learning English among students on lower stages of 8-year Grammar School (Diploma thesis). University of Masaryk. Retrieved from http://is.muni.cz/th/237053/pedf_m/Bednarova_diploma_thesis.pdf

Chambers, G. N. (1999). Motivating Language Learners (No. 12). Clevedon: Multilingual Matters.

Dörnyei, Z. (2001a). Motivational strategies in the language classroom (p. 143). Cambridge: Cambridge University Press.

Falout, J. (2012). Coping with de-motivation: EFL learners' re-motivation processes. The Electronic Journal for English as a Second Language, 16(3), 1-29.

Hosseini, S. A., \& Jafari, S. M. (2014). Possible de-motivating factors for secondary school students. International Journal of Language Learning and Applied Linguistics World, 5(3), 188-201.

Gorham, J., \& Christophel, D. M. (1992). Students' perceptions of teacher behaviours as motivating and de-motivating factors in college class. Communication Quarterly, 40, 239-252. Retrieved from http://dx.doi.org/10.1080/01463379209369839

Gorham, J., \& Millette, D. (1997). A comparative of analysis of teacher and student perceptions of sources of motivation and de-motivation in college classes. Communication Education, 46, 245-261. Retrieved from http://dx.doi.org/10.1080/03634529709379099

Kaivanpanah, Sh., \& Ghasemi, Z. (2011). An investigation into sources of De-motivation in second language learning. Iranian Journal of Applied Linguistics (IJAL), 14(2), 89-110.

Molavi, A., \& Biria, R. (2013). EFL learning among motivated and de-motivated Iranian seminary. Latin American Journal of Content and Language Integrated Learning, 6(1), 55-66.

Muhonen, J. (2004). Second language de-motivation: Factors that discourage pupils from learning the English language (Master's Thesis). University of Jyvaskyla.

Oxford, R. L. (1998). The unravelling tapestry: Teacher and course characteristics associated with de-motivation in the language classroom. De-motivation in foreign language learning. Paper presented at the TESOL 98 Congress. Seattle, USA.

Sakai, H., \& Kikuchi, K. (2009). An analysis of de-motivators in the EFL classroom. System, 37, 57-69. Retrieved from http://dx.doi.org/10.1016/j.system.2008.09.005

Ushioda, E. (1998). Effective motivational thinking: A cognitive theoretical approach to the study of language learning motivation. In E. A. Soler, \& V. C. Espurz (Eds.), Current Issues in English Language Methodology (pp. 77-89). Spain: Universita Jaume I.

Ushioda, E. (2001). Language learning at university. Exploring the role for motivational thinking. In Z. Dörnyei, 
\& R. Schmidt (Eds.), Motivation and second language acquisition (pp. 93-125). University of Hawai'i Press.

Williams, M., Burden, R. L., \& Lanvers, U. (2002). 'French is the language of love and stuff': Student perceptions of issues related to motivation in learning a foreign language. British Educational Research Journal, 28, 504-528.

Zhang, Q. (2007). Teacher misbehaviours as learning de-motivators in college classrooms: A cross cultural investigation in China, Germany, Japan and the United States. Communication Education, 56, $209-227$.

\section{Copyrights}

Copyright for this article is retained by the author(s), with first publication rights granted to the journal.

This is an open-access article distributed under the terms and conditions of the Creative Commons Attribution license (http://creativecommons.org/licenses/by/3.0/). 